\title{
Frequency, Distribution and Severity of Prevalent Osteoporotic Vertebral Fractures in Postmenopausal Women
}

\author{
Postmenopozal Kadınlarda Osteoporotik Omurga Kirıklarının Sıklık, \\ Dağılım ve Şiddeti
}

Cumhur KILINCER ${ }^{1}$, Derya DEMIRBAG KABAYEL ${ }^{2}$, Bekir CAGLI $^{3}$, Ercument UNLU ${ }^{3}$, Barbara WICKI ${ }^{4}$, Ferda OZDEMIR ${ }^{2}$

${ }_{1}^{1}$ Trakya University, Faculty of Medicine, Department of Neurosurgery, Edirne, Turkey

${ }^{2}$ Trakya University, Faculty of Medicine, Department of Physical Therapy and Rehabilitation, Edirne, Turkey

${ }^{3}$ Trakya University, Faculty of Medicine, Department of Radiology, Edirne, Turkey

${ }_{4}^{4} \mathrm{O}$ Clinical Investigation and Documentation, Dübendorf, Switzerland

Corresponding Author: Cumhur KILINCER / E-mail: ckilincer@hotmail.com

\begin{abstract}
AIM: Assessment of previous vertebral fractures provides useful information to predict future fracture risk. This study aimed to determine the frequency, distribution and severity of prevalent osteoporotic vertebral fractures in postmenopausal women.

MATERIAL and METHODS: Data on patient characteristics, bone densitometry values, and spine radiographs (T2-L5) were reviewed in 232 postmenopausal women admitted to our osteoporosis clinic.

RESULTS: Prevalent vertebral fractures were detected in 28 (12.1\%) women (95\%Cl: 7.8 16.3). Fifteen women (6.5\%) had mild fractures and 13 (5.6\%) had moderate or severe fractures according to Genant's semi-quantitative technique. The T-score was associated with the presence of prevalent vertebral fractures $(\mathrm{OR}=0.61 ; 95 \% \mathrm{Cl}: 0.38-0.96, \mathrm{P}=0.034)$. The most frequently fractured vertebrae were $\mathrm{T} 11$ and $\mathrm{T} 12$, followed by $\mathrm{T} 7$ and T9. Sixty percent of fractures were wedge-type while $40 \%$ were biconcave. The frequency of wedge-type fractures at the T11-T12 levels (93.8\%) was higher compared to that at all other levels $(44.1 \%)(P=0.001)$.

CONCLUSION: We determined the frequency, distribution, and severity of prevalent fractures and identified certain distribution patterns of fracture locations and types. To verify our results and detect possible predictive factors for fracture risk, population-based larger trials are needed.
\end{abstract}

KEYWORDS: Bone mineral density, Morphometry, Prevalence, Radiography, Thoracolumbar spine, Vertebral fracture

öz

AMAÇ: Geçirilmiş vertebral kırıkların değerlendirilmesi, gelecekteki kırık riskini tahmin etmede yararlı bilgiler sağlar. Bu çalışmada postmenopozal dönemdeki kadınlarda osteoporotik kırıkların sıklık, dağılım ve şiddetinin saptanması amaçlanmıştır.

YÖNTEM ve GEREÇLER: Osteoporoz polikliniğimize başvuran 232 postmenopozal kadına ait hasta özellikleri, kemik dansitometre değerleri ve omurga grafileri (T2-L5) gözden geçirildi.

BULGULAR: 28 (\%12.1) kadında (\%95 güvenlik aralığı: 7.8-16.3) omurga kırığı saptandı. Genant'ın yarı-kantitatif yöntemine göre, 15 kadın (\%6.5) hafif, 13 kadın ise orta ya da şiddetli kırığa sahipti. T-skoru vertebral kırık gelişmiş olmasıyla ilişkili bulundu (Odds oranı=0.61; \%95 güven aralığı: 0.38-0.96, P= 0.034). En sık kırık görülen omurlar T11 ve T12 iken, bunları T7 ve T9 izledi. Kırkların \%60'ı kama, \%40'ı bikonkav şekilliydi. T11 ve T12 seviyelerinde kama şekilli kırıkların sıklığı (\%93.8) diğer seviyelerdekine kıyasla (\%44.1) yüksekti $(P=0.001)$.

SONUÇ: Omurga kırıklarının sıklık, dağılım ve şiddeti saptanmış ve kırıkların yeri ve tiplerine dair belirli paternler bulunmuştur. Bulgularımızı doğrulamak ve kırık riskini tahmin etmekte kullanılacak muhtemel faktörleri saptamak için toplum tabanlı daha geniş çalışmalara gereksinim vardır.

ANAHTAR SÖZCÜKLER: Kemik mineral dansitesi, Morfometri, Prevalans, Radiografi, Torakolomber omurga, Omurga kırığı 


\section{INTRODUCTION}

Osteoporosis is the most prevalent bone disease with one in three women and one in five men at risk of an osteoporotic fracture worldwide (17). The most common osteoporotic fractures occur at the spine, hip, and wrist. Of particular concern are vertebral fractures because they can result in severe back pain, decreased mobility, loss of height, and deformity. Having had one or more vertebral fractures has been related to poorer quality of life (20) and higher longterm mortality (13)

Today, osteoporosis is considered a treatable condition. As treatment is generally based on the assessment of clinical risk factors followed by measurements of bone mineral density (BMD) using dual-energy X-ray absorptiometry (DXA) (10), identification of patients at risk for osteoporotic fractures and suggesting both lifestyle changes and pharmacotherapy may prevent many fractures. However, studies have demonstrated that a significant number of individuals with incident vertebral fractures have no osteoporosis according to the World Health Organization (WHO) diagnostic criteria (T-score $\geq-2.5$ ) $(19,27,29,30)$. Indeed, the best predictor of an osteoporotic fracture is a previous fracture. Even after adjusting for the effects of other risk factors such as age, weight, and BMD, it has been shown that a previous fracture is associated with a significantly increased risk of future fractures $(14,15)$. Therefore, assessment of previous vertebral fracture may provide useful information to predict fracture risk.

Little is known about the prevalence of osteoporotic vertebral fractures in specific populations because most osteoporotic vertebral fractures remain clinically asymptomatic. It has been reported that only $2 \%-12 \%$ of people with radiologically evident spine fracture(s) may be identified in primary care settings $(8,24,32)$. In addition to a prevalent fracture, it has been demonstrated that the risk of an incident fracture was related not only with the number of previous fractures, but the shape, severity, and location within the spine of the prevalent deformity (15). Detection of prior vertebral fractures along with a complete fracture mapping of the spine is of paramount importance to estimate future fracture risk, especially in high-risk patients. Therefore, the specific goal of this study focused on determining the frequency, distribution, and severity of prevalent osteoporotic vertebral fractures in a specific population of postmenopausal women from the Thracian region of Turkey.

\section{MATERIAL and METHODS}

\section{Study Design}

A retrospective analysis of data collected from patients admitted to the Outpatient Osteoporosis Clinic of Trakya University Hospital Physical Therapy and Rehabilitation Department between April 2004 and February 2005 was conducted. The hospital is the tertiary referral center of the Thracian (European) part of Turkey serving around 1.5 million people.
Patient demographics including age, height, weight, body mass index, concomitant medical disorders, and bone densitometry values were obtained from the medical files. For the evaluation of frequency, severity and distribution of osteoporotic vertebral fractures, thoracolumbar radiographs taken during routine visits at the clinic were assessed.

\section{Description of the Cohort and Definition of Prevalent and Incident Fractures}

The study included 232 women admitted to the outpatient clinic during the nominated time period. The mean age of the cohort was sixty years, with a range of 35 to 89 years.

A prevalent fracture was defined as any vertebral fracture detected at the baseline radiographic evaluation from the 232 patients. The data obtained from analysis of baseline radiographs of these 232 patients revealed the prevalent osteoporotic vertebral fractures and constituted the main findings of the study. 59 of the 232 patients had a second evaluation including a new set of thoracolumbar radiographs. In this subgroup, the duration between the baseline evaluation and the follow-up evaluation was 16.9 \pm 3.5 months (range: 8-25 months). Comparison of the baseline and the second evaluations of these 59 patients constituted a second set of data in this study and revealed the information about incident osteoporotic fractures. The term incident fracture indicates either worsening of fracture grade when the baseline and the second radiographs were compared, or a new fracture on a previously normal vertebra. The data of those 59 patients were compared statistically with patients without follow-up to investigate whether this group represents the whole cohort well.

\section{Bone Mineral Density (BMD)}

BMD measurements of the L1 to L4 lumbar spine using an antero-posterior projection DXA were made using a Hologic instrument (Hologic Inc. Bedford, MA, USA). The bone densitometer was calibrated daily using a phantom of the lumbar spine. Precision error for BMD measurements was determined based on standard International Society for Clinical Densitometry protocols (28).

\section{Assessment of Vertebral Fractures}

For the identification of vertebral fractures, radiographs were evaluated by an experienced radiologist (EÜ). Based on the quality of each radiograph assessed, not all 16 vertebrae levels (T2-L5) could be visualized for all included patients. Therefore, the exact number of visualized vertebrae was recorded for each patient; on average, 13.3 ( \pm 1.8 ) vertebrae were visualized.

The semi-quantitative (SQ) method of Genant (9) used to identify vertebral fractures is based on the reduction in vertebral body height (anterior, middle, and/or posterior height) and radiological characteristics of the fracture at the vertebral endplate. Fractures were graded on a 4-grade scale (Grade $0=$ normal to Grade 3 = severe fracture), where Grade 1 (mild) is a reduction of $20-25 \%$ in any height (anterior, 
middle, or posterior); Grade 2 (moderate) is a reduction of $26-40 \%$ in any height; and Grade 3 (severe) is a reduction of over $40 \%$ in any height. In addition, a total fracture grade (TFG) was calculated for each patient by summing the individual vertebral deformity scores, and a spinal fracture index (SFI) was calculated by dividing the TFG by the number of vertebrae evaluated. In addition to numeric grading, the shape of the fractured body was classified as either wedge (decreased anterior vertebral height), biconcave (decreased middle vertebral height), or crush-type (decreased posterior vertebral height) fracture. An example case is presented below in Figure 1.

\section{Illustrative Case (Figure 1)}

- Vertebral levels visible:T3-L2

- Number of levels visible: 12

- $\quad 1_{\text {st }}$ fracture level: T7

- 1 st fracture type: Biconcave

- 1 st fracture grade: Grade 2

- 2nd fracture level: T9

- 2nd fracture type: Biconcave

- 2nd fracture grade: Grade 3

- 3nd fracture level:T12

- 3nd fracture type: Biconcave

- 3nd fracture grade: Grade 1

- Total fracture grade: 6

- Spinal fracture Index: 0.5

\section{Statistical Analysis}

All results were expressed as the mean \pm standard deviation or percentages and the corresponding 95\% confidence intervals $(\mathrm{Cl})$. Baseline characteristics of patients with and without fractures were compared by univariate analyses, using the Student's t-test for continuous variables and chisquare testing for categorical variables. The Mann-Whitney $U$ test was used when the normality assumption was not satisfied. Logistic regression was used to analyze which factors were independently associated with prevalent or incident vertebral fractures. The significance level was set at 0.05. All analyses were performed using Intercooled Stata Version ${ }^{\mathrm{TM}}$ 12.1 (StataCorp LP, College Station, TX, USA).

\section{RESULTS}

The demographic, anthropometric, and laboratory data for the study cohort are shown in Table I. According to the WHO criteria, $19.8 \%$ of the patients had normal bone mass (T-score $\geq-1$ ), 49.2\% had osteopenia (T-score between -1 and -2.5 ), and $31.0 \%$ had osteoporosis (T-score $\leq-2.5$ ).

Prevalent vertebral fractures were detected in 28 of the 232 (12.1\%) patients (95\%Cl: 7.8-16.3). Fifteen women (6.5\%) had

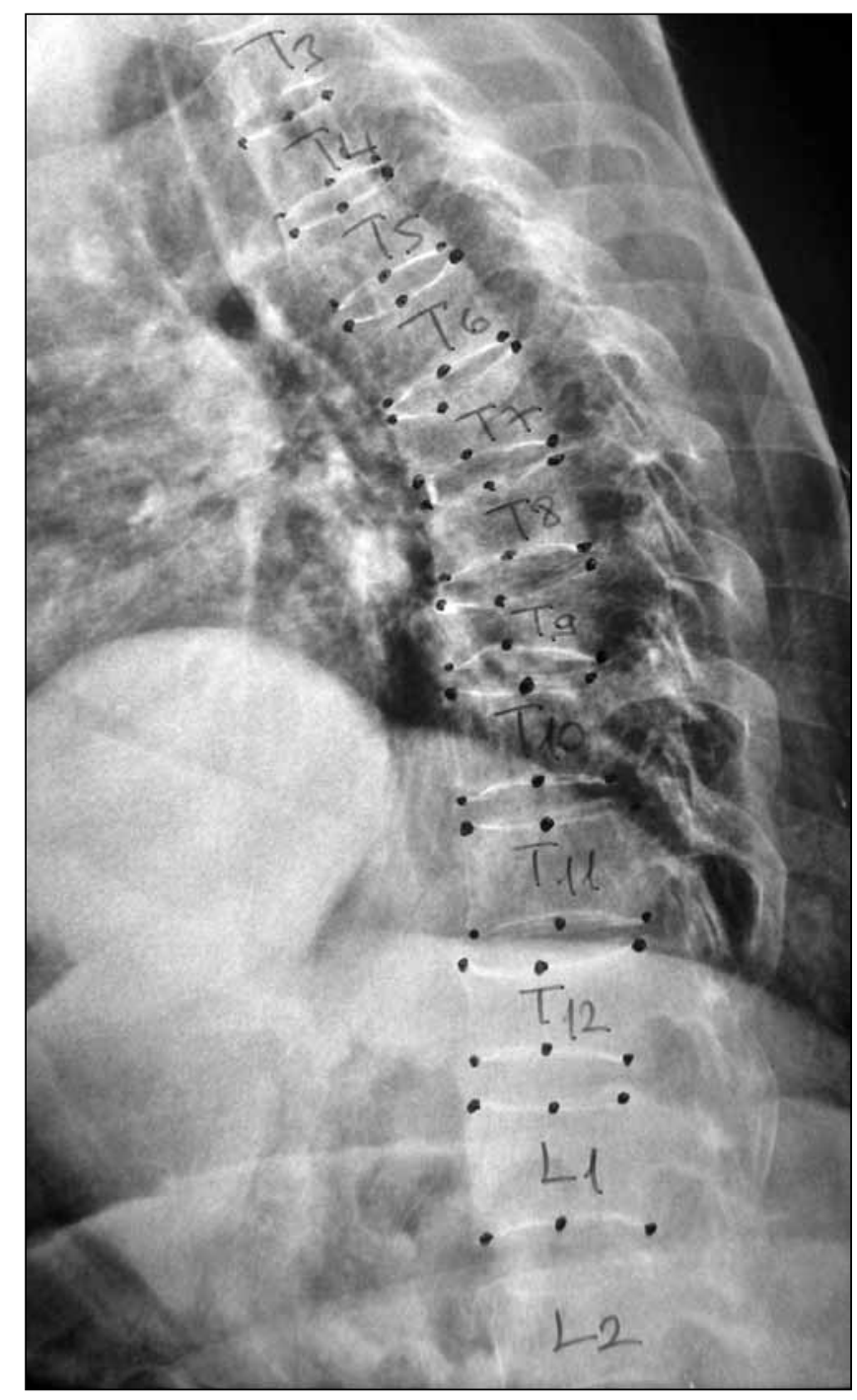

Figure 1: Illustrative case: Radiographic evaluation of a 62-yearold woman.

mild fractures, and $13(5.6 \%)$ had at least one moderate or severe fracture. The clinical and laboratory data distributed by patients with and without fracture are presented in Table II.

Overall, there were no significant differences between the patients with and without fractures in terms of age, height, and BMI (Table II). Lumbar spine T-scores, however, were significantly lower in patients within the fracture group $(-2.37 \pm 1.1)$ compared to those without fractures $(-1.86 \pm 1.0)$ $(p=0.025)$. In consideration of the WHO osteoporosis criteria, a higher rate of fracture was observed as the T-score decreased: only 3 out of $39(7.7 \%)$ patients with normal T-score had a fracture; 8 of 97 (8.2\%) patients with osteopenia had a fracture; and 13 of 61 (21.3\%) patients with osteoporosis had a fracture; there was a significant difference between the three groups $(P=0.044)$.One quarter of the patient population (24.8\%) had some type of systemic disease with the most common disorders being diabetes mellitus (5.5\%), thyroid disease (5.0\%), and hypertension (3.5\%). As some 
of these diseases had previously been described as a risk factor for osteoporosis/fracture (3), they all were analyzed. The frequency of concomitant disease types between the categorized patient groups was similar $(P>0.05)$.

Logistic regression analysis including the risk factors of age, gender, and height in combination with BMD or the T-score revealed that only the T-score was significantly and independently associated with the presence of prevalent vertebral fractures in the patient cohort (Odds Ratio $=0.61$; 95\%Cl: 0.38-0.96; $\mathrm{P}=0.034)$.

\section{Distribution of Prevalent Fractures}

Fifty fractures were detected from a total of 3083 visualized vertebrae. The location, type, and severity of vertebral fractures are presented in Table III. Fifty-six percent of the patients $(n=16 / 28)$ had one level, thirty-one percent of the patients $(n=8 / 28)$ had two levels, nine percent of the patients $(n=3 / 28)$ had four levels, and one patient had 6 levels of vertebral fractures. The most frequently fractured vertebrae were T12 (3.48\% of visualized T12 vertebrae) and T11 (3.46\% of visualized T11 vertebrae). Forty-eight of the 50 fractured vertebrae (96\%) were located between the T5-L2 levels.

Table I: Demographic, Anthropometric, and Laboratory Data (Total Cohort)

\begin{tabular}{|l|c|c|}
\hline Age (years) & Total (Mean) & Range \\
\hline Weight $(\mathbf{k g})$ & $60.00 \pm 9.00$ & $35-89$ \\
\hline Height $(\mathbf{c m})$ & $67.70 \pm 11.40$ & $44-123$ \\
\hline BMI $\mathbf{( k g / \mathbf { m } ^ { 2 } )}$ & $154.80 \pm 9.00$ & $65-178$ \\
\hline BMD $\left(\mathbf{g} / \mathbf{c m}^{2}\right)$ & $28.80 \pm 10.60$ & $17.90-36.20$ \\
\hline T-score & $0.85 \pm 0.10$ & $0.44-1.21$ \\
\hline Total Grade & $-1.92 \pm 1.10$ & $-4.80-1.28$ \\
\hline SFI & $0.35 \pm 1.30$ & $0-13.00$ \\
\hline
\end{tabular}

BMI: bone mineral index; BMD: bone mineral density; SFI: spine fracture index.

Table II: Clinical and Laboratory Data Distributed by Patients with and without Fracture

\begin{tabular}{|l|c|c|c|}
\hline Age (years) & $\begin{array}{c}\text { Fracture } \\
(\mathbf{n = 2 8})\end{array}$ & $\begin{array}{c}\text { No Fracture } \\
(\mathbf{n = 2 0 4 )}\end{array}$ & $\mathbf{P}$ \\
\hline Weight (kg) & $62.8 \pm 10.2$ & $59.6 \pm 8.7$ & 0.100 \\
\hline Height (cm) & $155.8 \pm 4.5$ & $154.7 \pm 9.4$ & 0.588 \\
\hline BMI (kg/m $\left.{ }^{2}\right)$ & $27.5 \pm 4.1$ & $29.0 \pm 11.2$ & 0.536 \\
\hline BMD $\left(\mathbf{g} / \mathbf{c m}^{2}\right)$ & $0.85 \pm 0.1$ & $0.84 \pm 0.1$ & 0.759 \\
\hline T-score & $-2.37 \pm 1.1$ & $-1.86 \pm 1.0$ & $\mathbf{0 . 0 2 5}$ \\
\hline Total Grade & $2.89 \pm 2.62$ & 0 & - \\
\hline SFI & $0.21 \pm 0.12$ & 0 & - \\
\hline
\end{tabular}

BMI: bone mineral index; BMD: bone mineral density; SFI: spine fracture index.
Thirty (60\%) fractures were wedge-type deformities and 20 (40\%) biconcave. Fifteen of 16 (93.8\%) fractures occurring at the T11 and T12 levels were wedge-type compared to $44.1 \%$ of those at all other levels $(P=0.001)$.

Twenty-four of the 50 fractures (48\%) were typed as Grade 1 fractures, 21 (42\%) Grade 2, and 5 (10\%) Grade 3. T11 and T12 vertebrae had the highest total fracture grades (14 and 13 points, respectively) and SFI (0.061 and 0.056 points, respectively), followed by $\mathrm{T} 9$ and $\mathrm{T} 7$ levels.

\section{Incident Fractures}

The subset of patients with the second set of radiographic data $(n=59)$ were statistically similar to those without the follow-up radiographs in terms of age, height, BMI, BMD, $\mathrm{SFI}$, total fracture grade and fracture rates (Table IV). There was however, a significant difference between the two populations when considering the characteristics of weight and T-score.

Three of 59 patients with follow-up radiographs $(5.1 \%)$ had newly developed fractures compared to their baseline evaluation after an average of 17.1 months follow-up. Thus, the yearly incidence of an osteoporotic fracture corresponds to $3.6 \%$ in this cohort. These three patients included: 1) a 56-year-old woman with a Grade 1 wedge fracture at the T12 level who developed another Grade 1 wedge fracture at T11; 2) a 68-year-old women with a Grade 2 biconcave fracture at the L1 level who developed a Grade 2 wedge fracture at the L4 level; and 3) a 60-year-old woman without a previous fracture who developed a Grade 1 wedge fracture at the T11 level.

Comparison of patients with and without incident fractures is presented in Table V. Although the three patients with incident fractures were slightly taller $(P=0.127)$ and the rate of having a previous fracture was higher $(P=0.086)$, there were no significant differences between patients with and without incidental fractures (Table V). Logistic regression analysis showed that after adjusting for age, weight, and T-score, the relative risk increased by a factor of 1.31 per $10 \mathrm{~cm}$ increase in height (95\%Cl: $0.88-1.94, \mathrm{P}=0.187$ ). No factors were found to have an effect on the occurrence of incident fractures.

\section{DISCUSSION}

Based on our evaluation of the frequency, distribution, and severity of prevalent vertebral fractures in postmenopausal women, these fractures were observed in $12 \%$ of the patients, where around half had moderate or severe fractures. The risk of fracture significantly increased as the T-scores decreased. In addition, only the T-score was found to be an independent predictive factor for fracture risk. T11 and T12 levels were the most frequent fracture location. Three of 59 patients with follow-up radiographs had additional fractures during 17.1 months of follow-up on average, corresponding to $3.6 \%$ yearly incidence of new fractures within this cohort.

Our knowledge regarding the prevalence of osteoporotic fractures is limited due to the high cost and difficulties 
related with conducting population-based trials and because most osteoporotic vertebral fractures remain asymptomatic. Moreover, the studies should be replicated for each specific population, since frequency, severity, and impact of osteoporosis differs worldwide geographically, due to environmental and racial differences (11). In a Spanish population-based study (25) the prevalence of vertebral fractures in postmenopausal women was $21.4 \%$ and $9.7 \%$ for moderate and severe fractures respectively. One of the largest studies on frequency of osteoporotic fractures was a cross-sectional, population-based trial with 15570 men and women aged 50-79 years from 19 European countries sampled randomly published by the European Vertebral Osteoporosis Study (EVOS) (22). Using Eastell's morphometric method (4), the prevalence of vertebral fractures was $20.2 \%$ for women. Of note, Eastell's method gives similar results to those obtained with the Genant method. The latter is thought to be more objective and reproducible than other qualitative methods (6), and has been considered as the gold standard for assessing vertebral fractures (26). However, some limitations include the requirement for highly experienced readers and modest reproducibility between readers, particularly for mild vertebral fractures $(7,23)$. Indeed, the fracture prevalence in the EVOS study dropped to $12.0 \%$ after using the McCloskey

Table III: Location of Vertebral Fractures and Frequency by Level

\begin{tabular}{|c|c|c|c|c|c|c|c|}
\hline $\begin{array}{c}\text { Vertebral } \\
\text { level }\end{array}$ & $\begin{array}{l}\text { Number of } \\
\text { vertebrae } \\
\text { investigated }\end{array}$ & $\begin{array}{l}\text { Number of } \\
\text { fractured } \\
\text { vertebra }\end{array}$ & $\begin{array}{l}\text { Fracture } \\
\text { rate }(\%)\end{array}$ & $\begin{array}{c}\text { Fracture } \\
\text { types }^{1}\end{array}$ & Fracture grades & Total grade & $\mathbf{S F I}^{2}$ \\
\hline T2 & 50 & 0 & 0.00 & - & - & - & 0 \\
\hline T3 & 150 & 0 & 0.00 & - & - & - & 0 \\
\hline T4 & 193 & 0 & 0.00 & - & - & - & 0 \\
\hline T5 & 204 & 2 & 0.98 & $1 \mathrm{~W}, 1 \mathrm{~B}$ & $1 \mathrm{Gr} 1,1 \mathrm{Gr} 2$ & 3 & 0.015 \\
\hline T6 & 215 & 3 & 1.40 & $1 \mathrm{~W}, 2 \mathrm{~B}$ & $2 \mathrm{Gr} 1,1 \mathrm{Gr} 3$ & 5 & 0.023 \\
\hline T7 & 221 & 6 & 2.71 & $3 \mathrm{~W}, 3 \mathrm{~B}$ & $2 \mathrm{Gr} 1,3 \mathrm{Gr} 2,1 \mathrm{Gr} 3$ & 11 & 0.050 \\
\hline T8 & 225 & 3 & 1.33 & $2 \mathrm{~W}, 1 \mathrm{~B}$ & $1 \mathrm{Gr} 1,2 \mathrm{Gr} 2$ & 5 & 0.022 \\
\hline T9 & 228 & 7 & 3.07 & $3 \mathrm{~W}, 4 \mathrm{~B}$ & $3 \mathrm{Gr} 1,3 \mathrm{Gr} 2,1 \mathrm{Gr} 3$ & 12 & 0.053 \\
\hline T10 & 229 & 3 & 1.31 & $2 \mathrm{~W}, 1 \mathrm{~B}$ & $1 \mathrm{Gr} 1,2 \mathrm{Gr} 2$ & 5 & 0.022 \\
\hline T11 & 230 & 8 & 3.48 & $7 \mathrm{~W}, 1 \mathrm{~B}$ & $4 \mathrm{Gr} 1,2 \mathrm{Gr} 2,2 \mathrm{Gr} 3$ & 14 & 0.061 \\
\hline T12 & 231 & 8 & 3.46 & $8 \mathrm{~W}$ & $3 \mathrm{Gr} 1,5 \mathrm{Gr} 2$ & 13 & 0.056 \\
\hline L1 & 231 & 4 & 1.73 & $2 \mathrm{~W}, 2 \mathrm{~B}$ & $3 \mathrm{Gr} 1,1 \mathrm{Gr} 2$ & 5 & 0.022 \\
\hline $\mathbf{L 2}$ & 226 & 4 & 1.77 & $1 \mathrm{~W}, 3 \mathrm{~B}$ & 2 Gr1, 2 Gr2 & 6 & 0.027 \\
\hline $\mathbf{L 3}$ & 203 & 0 & 0.00 & - & - & & 0.000 \\
\hline L4 & 144 & 1 & 0.69 & $1 \mathrm{~B}$ & $1 \mathrm{Gr} 1$ & 1 & 0.007 \\
\hline $\mathbf{L 5}$ & 103 & 1 & 0.97 & $1 \mathrm{~B}$ & $1 \mathrm{Gr} 1$ & 1 & 0.010 \\
\hline Total & 3083 & 50 & 22.9 & $30 \mathrm{~W}, 20 \mathrm{~B}$ & 24 Gr1, 21 Gr2, 5 Gr3 & 81 & 0.366 \\
\hline
\end{tabular}

${ }^{1}$ W: Wedge fracture; B: Biconcave fracture; Gr: Grade.

${ }^{2}$ SFI: Spinal fracture index $=$ Total grade/number of vertebrae investigated.

Table IV: Demographic, Anthropometric, Laboratory, and Clinical Data in Patients with and without Follow-Up

\begin{tabular}{|c|c|c|c|}
\hline & Patients without follow-up ( $n=173$ ) & Follow-up group $(n=59)$ & $\mathbf{P}$ \\
\hline Age (years) & $59.6 \pm 9.0$ & $61.1 \pm 8.9$ & 0.290 \\
\hline Weight (kg) & $69.1 \pm 11.6$ & $63.7 \pm 10.1$ & 0.003 \\
\hline Height (cm) & $154.8 \pm 9.6$ & $154.8 \pm 6.8$ & 0.970 \\
\hline BMI $\left(\mathbf{k g} / \mathbf{m}^{2}\right)$ & $29.6 \pm 11.9$ & $26.4 \pm 3.8$ & 0.065 \\
\hline BMD $\left(\mathrm{g} / \mathrm{cm}^{2}\right)$ & $0.86 \pm 0.1$ & $0.82 \pm 0.1$ & 0.127 \\
\hline T-score & $-1.81 \pm 1.1$ & $-2.24 \pm 1.0$ & 0.013 \\
\hline Total Grade & $0.29 \pm 1.1$ & $0.51 \pm 1.8$ & 0.277 \\
\hline SFI & $0.023 \pm 0.078$ & $0.036 \pm 0.123$ & 0.266 \\
\hline Prevalent Fracture (\%) & $17 / 173(9.8 \%)$ & $11 / 59(18.6 \%)$ & 0.073 \\
\hline
\end{tabular}

BMI: bone mineral index; BMD: bone mineral density; SFI: spine fracture index. 
Table V: Demographic, Anthropometric, Laboratory, and Clinical Data in Patients with and without Incidental Fractures

\begin{tabular}{|l|c|c|c|}
\hline & $\begin{array}{c}\text { Patients with no fracture progression } \\
(\mathbf{n = 5 6 )}\end{array}$ & $\begin{array}{c}\text { Patients with fracture progression } \\
(\mathbf{n = 3})\end{array}$ \\
\hline Age (years) & $61.1 \pm 9.0$ & $61.0 \pm 9.9$ & 0.985 \\
\hline Weight (kg) & $63.5 \pm 10.2$ & $68.5 \pm 9.2$ & 0.500 \\
\hline Height (cm) & $154.5 \pm 6.7$ & $162.0 \pm 2.8$ & 0.127 \\
\hline BMI (kg/m $)$ & $26.4 \pm 3.8$ & $26.2 \pm 4.4$ & 0.947 \\
\hline BMD $\left(\mathbf{g} / \mathbf{c m}^{2}\right)$ & $0.82 \pm 0.1$ & $0.85 \pm 0.1$ & 0.691 \\
\hline T-Score & $-2.23 \pm 1.0$ & $-2.47 \pm 0.4$ & 0.741 \\
\hline Total Grade & $0.48 \pm 1.85$ & $1.0 \pm 1.0$ & 0.634 \\
\hline SFI & $0.034 \pm 0.13$ & $0.077 \pm 0.08$ & 0.564 \\
\hline Prevalent Fracture (\%) & $9 / 56(19.1 \%)$ & $2 / 3(66.7 \%)$ & 0.086 \\
\hline
\end{tabular}

BMI: bone mineral index; BMD: bone mineral density; SFI: spine fracture index.

method (16). This effect can be explained by the fact that the McCloskey method uses much more restrictive criteria in the definition of vertebral fracture than the Eastell or Genant methods. Generally, the differences between methods were more prominent for mild fractures. For moderate or severe fractures (the more clinically relevant fracture types), agreement between the methods is better.

In another population-based study, Clark et al. found the rate of prevalent vertebral fractures in 1922 randomly selected women (50 years and older) from five Latin American countries (Argentina, Brazil, Colombia, Mexico, and Puerto Rico) to be 11.2\% (95\%Cl: 9.23-13.4) (2). Epidemiological data related to osteoporotic vertebral fractures in Turkey are scarce. The Mediterranean Osteoporosis Study (MEDOS) (12) suggests that the hip fracture rate in Turkey is rather low. This finding is partly supported Tüzün et al. (31). The EVOS study reported a higher prevalence of vertebral fractures in Scandinavian countries (27.8\% for Sweden) and lower rates for some Southern European countries (15.9\% for Turkey) and Russia (12.7\%) (22). From a cohort of 934 osteoporotic women, older than 50 years of age, who visited a musculoskeletal disease outpatient clinic in Turkey, $20.8 \%$ had some type of previous osteoporotic fracture; the authors reported that $11.5 \%$ had prevalent vertebral fractures using Genant's criteria (21). This number is in line with the rate of prevalent vertebral fractures in our population (12.1\%), which suggests that Turkey may be categorized in the moderate to low-risk countries, as in the case with the hip data.

Numerous factors have been proposed and studied to determine the risk of osteoporotic fractures. Some of these factors are classified as unalterable and include: race/ genetics, female gender, higher age, early menopause, tall stature, and a previous history of osteoporotic fracture. Other factors such as low BMD, low BMI, decreased physical activity, smoking, excessive alcohol intake, steroid use, risk factors for falls, calcium intake and dietary factors can be modified. Some studies suggest that anthropologic characteristics are predictors of fracture risk $(2,33)$. Although the retrospective nature of study prevented the documentation of all possible effectual factors on fracture risk, we found that patients with fractures were slightly older, thinner, and taller than those with no fracture. Nevertheless, these differences did not reach statistical significance probably because of the small sample size.

Lunt et al. (15) demonstrated that the risk of subsequent vertebral fractures is importantly influenced by some characteristics of previous fractures such as the number, shape, and location of them. We found that the majority of osteoporotic fractures were located at T5-L2 levels. Three regions are mostly affected by fractures: T7-T8-T9 region, T11-T12 region, and L1-L2 region. This distribution is line with Lunt et al. who reported fractures being most common around the T7-T8 and T12-L1 levels (15). These two regions anatomically correspond to the apex of thoracic kyphosis and transitional vertebrae of thoracolumbar junction, respectively. The apex of thoracic kyphosis has a greater distance between the axis of rotation and central plumb line. Thus, these cases have a greater bending moment that can increase fracture risk (1). On the other hand, transitional vertebrae of the thoracolumbar junction have increased mobility, causing more mechanical stress. From the biomechanical point of view, having more fragility fractures in these two regions is consistent.

It has been reported that the relative risk of subsequent fractures is related with the shape of the prevalent deformity. Lunt et al. reported a relative risk of 5.9 if the anterior and mid-heights were reduced, the relative risk decreased to 1.6 if the posterior and mid-heights were reduced (15). In other words, wedge fractures carry a much greater subsequent fracture risk than crush-type fractures. This is biomechanically relevant because wedge fractures promote kyphosis. Increased kyphosis forces the spine to bend anteriorly due to a greater bending moment (1). In the current study, most of the fractures were wedge-type, and the remaining biconcave. There was no crush-type fracture in our series. We found that 
frequency of wedge-type fractures at the T11-T12 levels was higher compared to that of all other levels. However, due to our low number of total fractures, we believe it may be incorrect to conclude that there is a different distribution of fracture types.

With the possibility to re-evaluate 59 patients, we had the opportunity to observe subsequent fractures during followup. Despite the limited patient number, our data regarding incident fractures were in line with previous publications $(15,18)$. Lunt et al. reported that location of the prevalent deformity within the spine was important to determine risk of future fractures (15). They found that the relative risk of an incident fracture within three vertebrae of a prevalent deformity was greater than the risk in more distant vertebrae. Melton et al. reported that new fractures occur most likely in nearby vertebrae, and more frequently in the mid-thoracic or thoracolumbar regions of the spine (18), as we observed in the three patients with further fractures in our series.

The yearly incidence of new fractures of $3.6 \%$ in this cohort is much higher than the previously reported annual incidence of vertebral fractures in Europe $(1.07 \%$ for women and $0.57 \%$ for men) (5). Because the current study is performed in a specific group of patients, and not a population-based trial, the results should be approached with caution. The prevalence and incidence from the current study reflects the profile of postmenopausal women who were admitted to our osteoporosis clinic, and should not be generalized to the whole Turkish population. The most important limitation of this study is the low number of patients evaluated, which possibly prevented the determination of factors affecting prevalent and incident fractures. Nevertheless, the frequency and distribution of prevalent osteoporotic fractures in our cohort are in line with published results of other countries and the limited papers reflecting the Turkish population (12, 21).

Detection of prevalent vertebral fractures and their characteristics are important to estimate future fracture risk, especially in high-risk patients. In the current study, we determined the frequency, distribution and severity of prevalent fractures in postmenopausal women admitted to the tertiary referral center of our region. We identified certain distribution patterns of fracture locations (thoracolumbar junction and apex of thoracic kyphosis) and fracture types. To verify our results and detect possible predictive factors for fracture risk, population-based, larger trials are needed.

\section{REFERENCES}

1. Benzel EC: Biomechanics of Spine Stabilization. Rolling Meadows, IL: American Association of Neurological Surgeons, 2001: 37

2. Clark P, Cons-Molina F, Deleze M, Ragi S, Haddock L, Zanchetta JR, Jaller JJ, Palermo L, Talavera JO, Messina DO, Morales-Torres J, Salmeron J, Navarrete A, Suarez E, Pérez CM, Cummings SR: The prevalence of radiographic vertebral fractures in Latin American countries: The Latin American Vertebral Osteoporosis Study (LAVOS). Osteoporos Int 20: 275-282, 2009

3. Cummings SR, Melton LJ: Epidemiology and outcomes of osteoporotic fractures. Lancet 359(9319): 1761-1767, 2002

4. Eastell R, Cedel SL,Wahner HW, Riggs BL, Melton LJ: Classification of vertebral fractures. J Bone Miner Res 6:207215, 1991

5. EPOS Group: Incidence of vertebral fracture in Europe. Results from the European Prospective Osteoporosis Study (EPOS). J Bone Miner Res 17(4): 716-724, 2002

6. Ferrar L, Jiang G, Adams J, Eastell R: Identification of vertebral fractures:un update. OsteoporisInt 16: 717-728, 2005

7. Ferrar L, Jiang G, Schousboe JT, DeBold CR, Eastell R: Algorithm-based qualitative and semiquantitative identification of prevalent vertebral fracture: Agreement between different readers, imaging modalities, and diagnostic approaches. J Bone Miner Res 23: 417-424, 2008

8. Gehlbach SH, Bigelow C, HeimisdottirM, May S, Walker M, Kirkwood JR: Recognition of vertebral fracture in a clinical setting. OsteoporosInt 11:577-582, 2000

9. Genant HK, Wu CY, van Kuijk C, Nevitt MC: Vertebral fracture assessment using a semiquantitative technique. J Bone Miner Res 8: 1137-1148, 1993

10. Geusens PP, Lems WF, Verhaar HJ, Leusink G, Goemaere S, Zmierczack H, Compston J: Review and evaluation of the Dutch guidelines for osteoporosis. J EvalClinPract 12(5): 539-548, 2006

11. Holroyd C, Cooper C, Dennison E: Epidemiology of osteoporosis. Best Pract Res Clin Endocrinol Metab 22(5): 671-685, 2008

12. Johnell O, Gullberg B, Kanis JA, Allander E, Elffors L, Dequeker J, Dilsen G, Gennari C, Vaz LA, Lyritis G, Mazzuoli G, Miravet L, Passeri M, Cano PR, Rapado A, Ribot C: Risk factors for hip fracture in European women: The MEDOS Study. Mediterranean Osteoporosis Study. J Bone Miner Res 10: 1802-1815, 1995

13. Kado DM, Browner WS, Palermo L, Nevitt MC, Genant HK, Cummings SR: Vertebral fractures and mortality in older women: A prospective study. Study of Osteoporotic Fractures Research Group. Arch Intern Med 159: 1215-1220, 1999

14. Klotzbuecher CM, Ross PD, Landsman PB, Abbott TA III, Berger M: Patients with prior fractures have an increased risk of future fractures: A summary of the literature and statistical synthesis. J Bone Miner Res 15: 721-727, 2000

15. Lunt M, O'Neill TW, Felsenberg D, Reeve J,Kanis JA, Cooper C, Silman AJ, European Prospective Osteoporosis Study Group: Characteristics of a prevalent vertebral deformity predict subsequent vertebral fracture: Results from the European Prospective Osteoporosis Study (EPOS). Bone 33(4):505-513, 2003

16. McCloskey EV, Spector TD, Eyres KS, Fern ED, O'Rourke N, Vasikaran S, Kanis JA: The assessment of vertebral deformity: A method for use in population studies and clinical trials. OsteoporosInt 3: 138-147, 1993 
17. Melton III LJ, Atkinson EJ, O'Connor MK, O'Fallon WM, Riggs $\mathrm{BL}$ : Bone density and fracture risk in men. J Bone Miner Res 13(12): 1915-1923, 1998

18. Melton III LJ, Kallmes DF: Epidemiology of vertebral fractures: Implications for vertebral augmentation. Acadradiol 13: 538-545, 2006

19. Miller PD, Siris ES, Barrett-Connor E, Faulkner KG, Wehren LE, Abbott TA, Chen YT, Berger ML, Santora AC, Sherwood LM: Prediction of fracture risk in postmenopausal white women with peripheral bone densitometry: Evidence from the National Osteoporosis Risk Assessment. J Bone Miner Res 17(12): 2222-2230, 2002

20. Nevitt MC, Thompson DE, Black DM, Rubin SR, Ensrud K, Yates AJ, Cummings SR: Effect of alendronate on limitedactivity days and bed-disability days caused by back pain in postmenopausal women with existing vertebral fractures. Fracture Intervention Trial Research Group. Arch Intern Med 160: 77-85, 2000

21. Odabaşı E, Turan M, Tekbas F, Kutlu M: Evaluation of osteoporotic fractures in a group of Turkish Women. Turk $J$ Med Sci 39(1): 21-28, 2009

22. O'Neill TW, Felsenberg D, Varlow J, Cooper C, Kanis JA, Silman AJ:The European Vertebral Osteoporosis Study Group: The prevalence of vertebral deformity in European men and women: The European Vertebral Osteoporosis Study. J Bone Miner Res 11: 1010-1017, 1996

23. Prevrhal S, Krege JH, Chen P, Genant H, Black DM: Teriparatide vertebral fracture risk reduction determined by quantitative and qualitative radiographic assessment. Curr Med Res Opin 25:921-928, 2009

24. Sahota O, Worley A, Hosking DJ: An audit of current clinical practice in management of osteoporosis in Nottingham. J Public Health Med 22:466-472, 2000

25. Sanfélix-Genovés J, Reig-Molla B, Sanfélix-Gimeno G, Peiró S, Graells-Ferrer M, Vega-Martínez M, Giner V: The populationbased prevalence of osteoporotic vertebral fracture and densitometric osteoporosis in postmenopausal women over 50 in Valencia, Spain (the FRAVO study). Bone 47(3):610-616, 2010
26. Schousboe JT, Vokes T, Broy SB, Ferrar L, McKiernan F, Roux C, Binkley N: Vertebral fracture assessment: The 2007 ISCD official positions. J Clin Densitom 11: 92-108, 2008

27. Schuit SC, van der Klift $M$, Weel $A E$, de Laet $C E$, Burger $H$, Seeman E, Hofman A, Uitterlinden AG, van Leeuwen JP, Pols $\mathrm{HA}$ : Fracture incidence and association with bone mineral density in elderly men and women. The Rotterdam Study. Bone 34(1): 195-202, 2004

28. Shepherd JA, Lu Y, Wilson K, Fuerst T, Genant H, Hangartner TN, Wilson C, Hans D, Leib ES; International Society for Clinical Densitometry Committee on Standards of Bone Measurement: Cross-calibration and minimum precision standards for dual-energy x-ray absorptiometry: The 2005 ISCD official positions. J Clin Densitom 9:31-36, 2006

29. Siris ES, Miller PD, Barrett-Connor E, Faulkner KG, Wehren LE, Abbott TA, Berger ML, Santora AC, Sherwood LM: Identification and fracture outcomes of undiagnosed low bone mineral density in postmenopausal women. Results from the National Osteoporosis Risk Assessment. JAMA 286(22): 2815-2822, 2001

30. Sornay-Rendu E, Munoz F,Garnero P Duboeuf F, Delmas PD: Identification of osteopenic women at high risk of fracture: The OFELY Study. J Bone Miner Res 20(10): 1813-1819, 2005

31. Tüzün $S$,Eskiyurt $N$, Akarirmak $U$, Saridogan $M$, Senocak M, Johansson H, Kanis JA, Turkish Osteoporosis Society: Incidence of hip fracture and prevalence of osteoporosis in Turkey: The FRACTURK study. OsteoporosInt 23: 949-955, 2012

32. vanStaa TP, Dennison EM, Leufkens HGM, Cooper C: Epidemiology of fractures in England and Wales. Bone 29: 517-522, 2001

33. Waterloo S, Ahmed LA, Center JR, Eisman JA, Morseth B, Nguyen ND, Nguyen T, Sogaard AJ, Emaus N: Prevalence of vertebral fractures in women and men in the populationbased Tromsø Study. BMC Musculoskelet Disord 13:3, 2012 